\title{
A transformação de alimentos tradicionais em produtos simbólicos:
}

um estudo de caso com o Queijo Canastra

\section{The transformation of traditional food into symbolic product:}

the case study of Canastra Cheese

Bianca Silva da Cruz ${ }^{1}$

Lertiane Maria Lima Moreira ${ }^{2}$

Objetivo: Atualmente a gastronomia nacional e mundial vive um momento de valorização e certificação de seus ingredientes tradicionais, a fim de se destacarem e sobreviverem em um mercado industrial cada vez mais competitivo. No Brasil, o Queijo Canastra é um exemplo disso. Nosso objetivo, então, é expor o processo que transformou o queijo artesanal produzido na Serra da Canastra em um símbolo gastronômico e cultural.

Metodologia: Por meio de um levantamento bibliográfico, foi feito um estudo de caso sobre o Queijo Canastra. Na bibliografia, buscamos dados sobre a história de Minas Gerais, sua ocupação e produção queijeira, além de expor e discutir os elementos mais relevantes na transformação do Queijo Canastra, de um alimento tradicional/rural para um produto gastronômico.

Resultados: Neste trabalho destacamos quatro questões que juntas propiciaram a ressignificação do Queijo Canastra. A primeira expõe a chancela do Instituto do Patrimônio Histórico e Artístico Nacional (Iphan) nesse produto, decorrente do processo de registro do Modo Artesanal de Fazer Queijo Minas, que na prática atesta a tradição e a importância cultural desse alimento para o país. A segunda questão trata do reconhecimento desse queijo como um produto de terroir, ou seja, um produto cujos aspectos únicos advindos daquela região em conjunto com o trabalho artesanal o tornam diferenciado e passível de ações de salvaguarda. A terceira disserta sobre a obtenção da Indicação de Procedência, uma certificação utilizada para assegurar a tradição em relação ao modo de preparo e comercialização do produto. Por fim, a quarta analisa as ações de marketing desenvolvidas por um grupo de produtores do Queijo Canastra, respaldadas nas certificações conquistadas, cujo intuito era fazer a promoção desse queijo e torná-lo valorizado perante a gastronomia e a sociedade. Assim, analisando essas questões conjuntamente, verificam-se relações contraditórias, que se estabelecem através de interesses distintos e nem sempre convergentes. É possível afirmar, por ora, que os benefícios advindos desses processos de valorização do queijo não são equitativamente distribuídos entre os agentes que participam dele.

Contribuição: Este trabalho tem um potencial de contribuição teórica às diferentes áreas que abrangem os estudos sobre alimentação, incluindo as ciências sociais e a história, visto que, ao analisar um dos caminhos de transformação dos alimentos tradicionais em produtos valorizados monetária e simbolicamente, é possível registrar um pouco das mudanças sociais que vêm ocorrendo na gastronomia brasileira e na forma de nos alimentarmos. Além disso, as observações acerca das contradições levantadas em nosso estudo podem servir para pensar os casos de alimentos tradicionais que tem passado por processos semelhantes de valorização. 
Palavras-chave: Queijo Canastra; estudo de caso; valorização; terroir; tradição. Keywords: Canastra Cheese; case study; valorization; terroir; tradition.

1 Pós-graduada em Cozinha Brasileira no Centro Universitário Senac.

2 Pós-graduada em Cozinha Brasileira no Centro Universitário Senac. 